Review - Human \& Animal Health

\title{
Influence of Polymorphism of Vitamin D Receptor (Fok I) on Hypertension
}

\author{
Ivone Freires de Oliveira Costa Nunes ${ }^{1 *}$ \\ https://orcid.org/0000-0002-9890-1231 \\ Flaviane Alves de Pinho² \\ https://orcid.org/0000-0003-1925-5890
}

Maria do Socorro Pires e Cruz ${ }^{3}$

https://orcid.org/0000-0002-5509-3828

Adriana de Azevedo Paiva ${ }^{1}$

https://orcid.org/0000-0001-5089-4581

\section{Cecilia Maria Resende Gonçalves de Carvalho'}

https://orcid.org/0000-0002-8707-1447

${ }^{1}$ Federal University of Piauí, Postgraduate Program in Food and Nutrition, Teresina, Piauí, Brazil ${ }^{2}$ Federal University of Bahia, Department of Anatomy, Pathology and Clinics, Salvador, Bahia, Brazil ${ }^{3}$ Federal University of Bahia, Department of Veterinary Morphology, Teresina, Piauí, Brazil

Received: 2019.07.07; Accepted: 2020.02.14.

${ }^{*}$ Correspondence: ivonefreirescosta@ufpi.edu.br; Tel.: +55-86-32155863 (I.F.O.C.N)

\section{HIGHLIGHTS}

- Polymorphisms in Fokl encoding a VDR affects blood pressure.

- The FF genotype appears to increase the risk of hypertension.

\begin{abstract}
Evidence suggests that polymorphisms in the gene encoding a vitamin D receptor might affect blood pressure. The objective of this systematic review was to investigate the association between hypertension and vitamin D receptor (Fok I) gene polymorphism. A literature search was performed according to the PRISMA guidelines using the MEDLINE®/PubMed, Scopus, Cochrane Library CENTRAL, SciELO, and LILACS databases. The quality of case-control or cohort studies and studies based on cross-sectional methodology was evaluated using the Newcastle-Ottawa Scale and the protocol of Loney and coauthors [25], respectively. In this systematic literature search, 215 publications were identified, of which 10 were analyzed, including seven case-control studies, two cross-sectional studies, and one cohort study. The association between Fok I polymorphism and hypertension was reported in $60 \%$ of the publications and the risk for hypertension was shown to be related to FF and ff genotypes. In addition, Fok I polymorphism was shown to increase plasma renin activity, which plays an important role in regulating blood pressure. However, no association was observed between Fok I polymorphism and serum vitamin D levels. In conclusion, Fok I polymorphism plays an important role in hypertension.
\end{abstract}

Keywords: single nucleotide polymorphism; rs228570; blood pressure; $25(\mathrm{OH}) \mathrm{D}$; renin. 


\section{INTRODUCTION}

Arterial hypertension $(\mathrm{AH})$ is considered to be a risk factor for cardiovascular diseases and is a public health concern. The prevalence of $\mathrm{AH}$ is high among the elderly because it is known to progressively increase with age [1]. Recent studies have demonstrated an association between $\mathrm{AH}$ and vitamin $\mathrm{D}[2,3]$. Moreover, individuals with low levels of 25-hydroxyvitamin D $(25(\mathrm{OH}) \mathrm{D}$, a biomarker of vitamin D status in the body) are at a higher risk of developing $\mathrm{AH}$ than those with normal levels of $25(\mathrm{OH}) \mathrm{D}$ [4-7]. Vitamin D plays an important role in regulating endothelial function, inflammation, and the activity of the renin-angiotensinaldosterone system (RAAS) [8], which regulates blood pressure [5]. The active form-1,25 di-hydroxyvitamin $\mathrm{D}\left(1,25(\mathrm{OH})_{2} \mathrm{D}_{3}\right)$-binds to the nuclear vitamin $\mathrm{D}$ receptor (VDR) to produce a biological effect. Studies with VDR and 1a-hydroxylase knockout mice indicated that inadequate activation of RAAS influences hypertension. Renin expression and plasma angiotensin II production are increased in null VDR mice, leading to hypertension, cardiac hypertrophy, and increased water intake. In wild mice, i.e., mice with intact VDR, inhibition of calcitriol synthesis also leads to increased renin expression, whereas calcitriol injection leads to renin suppression [9].

VDR is expressed in several types of tissues, including the bone, adipose, immune system [4], as well as components of the cardiovascular system, such as aortic endothelium [10] and vascular smooth muscle[11]. In addition, VDR is highly expressed in pancreatic beta cells, small and large intestine, kidney tubular cells, bronchial and skin epithelial cells, endocrine glands, and certain reproductive tissues [12].

In humans, the regulation of blood pressure has a genetic influence of about 30-50\% [13]. The VDR gene is located on chromosome 12q13.1, and single nucleotide polymorphisms (SNPs) of this gene can affect blood pressure [14]. One of the most studied SNP of the VDR gene is Fok I (rs228570 or rs10735810). Fok I polymorphism can generate truncated proteins and is associated with increased risk for hypertension [14-16]. Fok I polymorphism is caused by a thymine-to-cytosine transition, which leads to a translational frameshift characterized by an extension of the open reading frame to the next initiation codon (ATG), resulting in the synthesis of a truncated 424-amino acid protein. In the 427-amino acid protein, ATG-encoded methionine (M1 form) was present in the f allele, whereas ACG-encoded methionine (M4 form) was present in the F allele [17].

The truncated protein in individuals with the FF genotype is thought to promote the development of $\mathrm{AH}$ by increasing the production of renin and angiotensin II [18]. The transcriptional activity of the truncated protein is suggested to be higher than that of the full-length protein. Moreover, the increased responsiveness of the truncated protein to $1,25(\mathrm{OH})_{2} \mathrm{D}_{3}$ might alter the function of VDR and vitamin $\mathrm{D}$ in cells and tissues [19].

Low levels of $25(\mathrm{OH})$ D combined with Fokl polymorphism have been associated with increased plasmatic renin activity and RAAS activity [20]. This suggests that $1,25(\mathrm{OH})_{2} \mathrm{D}_{3}$ can downregulate renin expression in humans, and increase cardiovascular and metabolic disease risk [21].

An in vitro study from the mid-2000s has described the functional significance of variable protein length by demonstrating that the transcriptional activity of VDR with Fok I-f SNP was lower than that of TFIIB factor (an RNA polymerase II specific transcript) with Fok I-F SNP [22]. Thus, due to the importance of the association between $\mathrm{AH}$ and Fok I polymorphism, we performed a systematic literature search to validate the hypothesis that patients with Fok I polymorphism have an increased risk for hypertension.

\section{MATERIAL AND METHODS}

\section{Search strategy}

The text continues here. A literature search was performed according to the PRISMA guidelines [23]. Two independent researchers (IFOCN and CMRGC) systematically searched the MEDLINE® (Medical Literature Analysis and Retrieval System Online)/PubMed, Scopus, Cochrane Library CENTRAL, SCIELO (Scientific Electronic Library Online), and LILACS (Latin American and Caribbean Literature in Health Sciences) databases between June 17, 2017 and December 9, 2018, with the combined use of the following three sets of keywords: (Genetic and Hypertension and Polymorphism VDR); (Vitamin D and Hypertension and Polymorphism); (VDR and Hypertension and Fok I).

\section{Inclusion and exclusion strategy}

No limits were set for the publication year of articles, or for the sex, age, and ethnicity of subjects. Original research studies in humans, available in full and published in English, were included. Review studies, studies conducted in pregnant women, animal studies, and in vitro studies were excluded. In cases where the 
publication was found on more than one platform, the publication from the first search was selected for analysis and the duplicates were excluded.

\section{Analysis of studies}

The selected manuscripts were analyzed by the authors of the present review for the method of patient selection, population characteristics, and study results. The quality of case-control and cohort studies was evaluated using the Newcastle-Ottawa scale [24] and that of cross-sectional studies was assessed according to the protocol of Loney and coauthors [25].

\section{RESULTS}

A total of 215 publications were selected from the database search. To complement the study information, a publication from another online source was added. The quality of 10 publications was evaluated, as shown in Figure 1 and Tables 1,2, and 3, and it was found that the studies were carried out in male and female subjects from Europe $(n=4)$, Asia $(n=2)$, Africa $(n=1)$, and North America $(n=3)$.

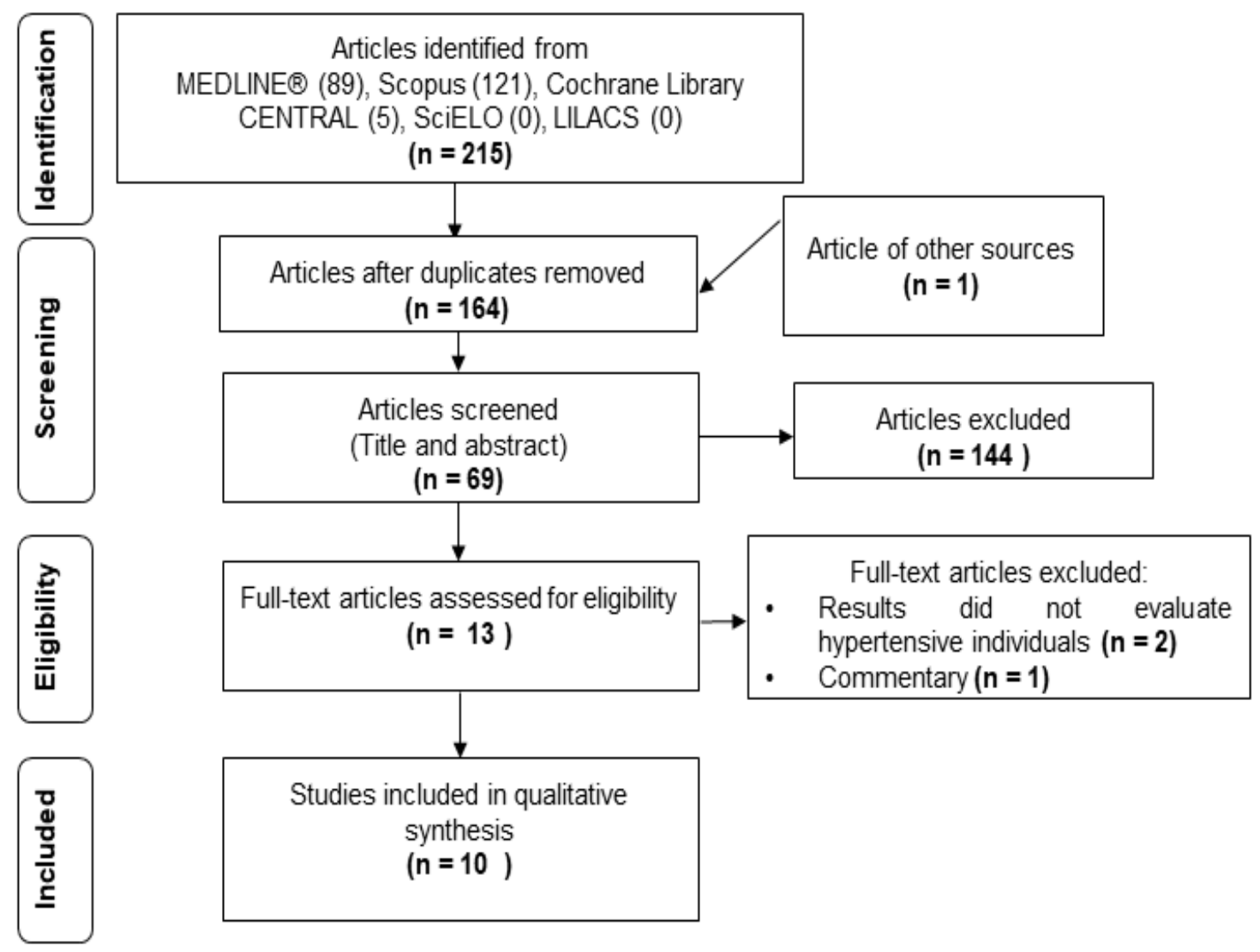

Figure 1. Research flow chart 
Table 1. Quality of case-control research evaluated.

\begin{tabular}{|c|c|c|c|c|c|c|c|}
\hline Items & $\begin{array}{l}\text { Ref. } \\
\text { [26] }\end{array}$ & $\begin{array}{l}\text { Ref. } \\
\text { [27] }\end{array}$ & $\begin{array}{l}\text { Ref. } \\
\text { [28] }\end{array}$ & $\begin{array}{l}\text { Ref. } \\
\text { [29] }\end{array}$ & $\begin{array}{l}\text { Ref. } \\
{[30]}\end{array}$ & $\begin{array}{l}\text { Ref. } \\
\text { [31] }\end{array}$ & $\begin{array}{l}\text { Ref. } \\
{[32]}\end{array}$ \\
\hline Selection & & & & & & & \\
\hline $\begin{array}{c}\text { Is the case definition } \\
\text { adequate? }\end{array}$ & - & - & - & - & - & - & - \\
\hline $\begin{array}{c}\text { Representativeness of the } \\
\text { case }\end{array}$ & $\star$ & $\star$ & $\star$ & $\star$ & $\star$ & $\star$ & $\star$ \\
\hline Selection of controls & 夫 & $\star$ & $\star$ & 夫 & 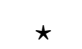 & - & 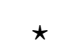 \\
\hline $\begin{array}{l}\text { Definition of controls } \\
\text { Compara-bility }\end{array}$ & $\star$ & $\star$ & - & $\star$ & $\star$ & $\star$ & $\star$ \\
\hline $\begin{array}{c}\text { Comparabi-lity of cases } \\
\text { and controls on the basis } \\
\text { of the design or analysis } \\
\text { Exposure }\end{array}$ & $\star \star$ & $\star \star$ & $\star \star$ & $\star \star$ & $\star \star$ & $\star \star$ & $\star \star$ \\
\hline $\begin{array}{l}\text { Ascertain-ment of } \\
\text { exposure }\end{array}$ & - & $\star$ & - & $\star$ & - & - & - \\
\hline $\begin{array}{l}\text { Same method of } \\
\text { ascertain-ment for the } \\
\text { cases and controls }\end{array}$ & - & $\star$ & - & $\star$ & - & - & $\star$ \\
\hline Non-response rate & $\star$ & $\star$ & $\star$ & $\star$ & $\star$ & $\star$ & $\star$ \\
\hline Score & 6 & 8 & 5 & 8 & 6 & 5 & 7 \\
\hline
\end{tabular}

Subtitle: $(\star)=1$ star $=1$ point; $(\star \star)=2$ stars $=2$ points; $(-)=$ zero point.

Table 2. Quality of cross-sectional surveys evaluated.

Items $\quad$ Ref. [33] $\quad$ Ref. [34]

\section{Are the study Methods valid?}

Are the study design and sampling method appropriate for the question?

Is the sampling frame appropriate?

Is the sample size adequate?

Are objective, suitable and standard criteria used for measurement of the health outcome?

Is the health outcome measured in an unbiased fashion?

In the response rate adequate? Are the refusers described?

What is the interpretation of the results?

Are the estimates of prevalence or incidence given with confidence intervals and in detail by subgroup, if appropriate?

What is the applicability of the results?

Are the study subjects and the setting described in detail and similar to those of interest to you? 
Table 3. Quality of the cohort study evaluated. Items

Ref. [35]

\section{Selection}

Representativeness of the case exposed cohort

Selection of the non-exposed cohort

Ascertainment of exposure

Demonstration that outcome of interest was not present at start of study

Comparability

Comparability of cohorts on the basis of the design or analysis

\section{Outcome}

Assessment of outcome

Was follow-up long enough for outcomes to occur Adequacy of follow up of cohorts

Score

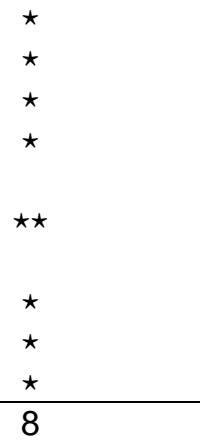

Subtitle: $(\star)=1$ star $=1$ point $(\star \star)=2$ stars $=2$ points 
Table 4. Summary of studies evaluated by type of methodological design.

\begin{tabular}{|c|c|c|c|c|}
\hline \multicolumn{5}{|c|}{ Case-control } \\
\hline Authors/Country/Year & $\begin{array}{l}\text { Age Group } \\
(y)\end{array}$ & SN & Other variables & Outcomes \\
\hline Swapna et al.[26]/India/2011 & $35-60$ & $C S=280 ; C T=200$ & $\begin{array}{l}\text {-Duration of disease, BMI, cigarettes, } \\
\text { alcohol, diabetes and lipid profile. }\end{array}$ & -Association between Fok I and HP risk. \\
\hline $\begin{array}{l}\text { Vaidya et al.[27]/United } \\
\text { States/2012 }\end{array}$ & $29-56$ & $C S=375 ; C T=146$ & -PRA and $25(\mathrm{OH}) \mathrm{D}$ & -Fok I was associated with lower PRA. \\
\hline Glocke et al.[28]/Germany/2013 & $>90$ and $<90$ & $C S=101 ; C T=208$ & -Weight, height and BMI. & -Potential influence of Fok I on DBP in men. \\
\hline Cottone et al.[29]/Italy/2014 & $18-75$ & $\mathrm{CS}=71 ; \mathrm{CT}=72$ & $\begin{array}{l}-25(\mathrm{OH}) \mathrm{D}, \mathrm{PRA}, \mathrm{BMI}, \mathrm{PTH}, \mathrm{Ca}^{2+} \text {, } \\
\text { phosphorus, estimated glomerular } \\
\text { filtration rate. }\end{array}$ & $\begin{array}{c}\text {-Higher DBP values in patients with ff } \\
\text { genotype. }\end{array}$ \\
\hline Jia et al.[30]/China/2014 & $47-72$ & $\mathrm{CS}=2.409 ; \mathrm{CT}=3.063$ & $\begin{array}{c}\text {-History of hypertension, diabetes, } \\
\text { cigarettes, BMI, lipid profile and } \\
\text { glucose. }\end{array}$ & -Association between Fok I and $\mathrm{AH}$ in men. \\
\hline Errouagui et al.[31]/Morocco/2014 & $35-68$ & $\mathrm{CS}=177 ; \mathrm{CT}=176$ & -FGP, lipid profile and $25(\mathrm{OH}) \mathrm{D}$. & $\begin{array}{l}\text {-Correlation between Fok I and } \mathrm{AH} \\
\text { susceptibility. }\end{array}$ \\
\hline Gussago et al.[32]/ltaly/2016 & $72-102$ & $C S=102 ; C T=163$ & $\begin{array}{l}\text {-Glucose, total cholesterol and uric } \\
\text { acid. }\end{array}$ & $\begin{array}{l}\text {-Association between Fok I and } \mathrm{AH} \\
\text { polymorphism. }\end{array}$ \\
\hline \multicolumn{5}{|c|}{ Cross-sectional } \\
\hline Authors/Country/Year & $\begin{array}{l}\text { Age Group } \\
(y)\end{array}$ & SN & Other variables & Outcomes \\
\hline $\begin{array}{l}\text { Ndiaye et al.[33]/ France, Greece, } \\
\text { Ireland, Portugal/2013 }\end{array}$ & $32-61$ & $P 1=1,912 ; P 2=1,755$ & -BMI. & $\begin{array}{c}\text {-Association with systolic and diastolic } \\
\text { pressure. }\end{array}$ \\
\hline Wang et al.[34]/United States/2014 & $47-62$ & $W=23,294 ; I=69,395$ & -Pulse pressure. & - No association between Fok I and AH. \\
\hline \multicolumn{5}{|c|}{ Cohort } \\
\hline Authors/Country/Year & $\begin{array}{l}\text { Age Group } \\
(\mathrm{y})\end{array}$ & SN & Other variables & Outcomes \\
\hline Wang et al.[35]/United States/2013 & $49-66$ & 885 & $\begin{array}{l}\text {-Cigarette, alcohol, exercise, } \\
\text { multivitamin, BMI, diabetes and } \\
\text { hypercholesterolemia. } \\
-25(\mathrm{OH}) \mathrm{D} \text { and } 1,25(\mathrm{OH})_{2} \mathrm{D}_{3 .}\end{array}$ & -Association between Fok I and $\mathrm{AH}$ risk. \\
\hline
\end{tabular}

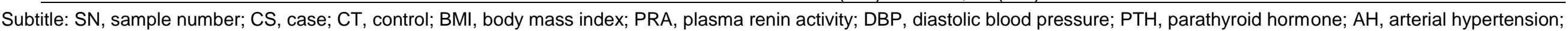
FGP, fasting glucose plasma; P, phase; W, women's genome health study; I, international consortium of blood pressure; (y), years. 


\section{DISCUSSION}

In this systematic literature review, studies examining the relationship between Fok I polymorphism and $\mathrm{AH}$ were identified and analyzed. In the study by Swapna and coauthors [26], the association between Fok I polymorphism and $\mathrm{AH}$ was assessed in Indian individuals of both sexes, ranging in age from 35 to 60 years, and grouped into hypertensive patients $(\mathrm{N}=280$, systolic blood pressure $>140 \mathrm{mmHg}$ or diastolic blood pressure $>90 \mathrm{mmHg}$ ) and control subjects $(\mathrm{N}=200$, systolic blood pressure of $120 \mathrm{mmHg}$ or diastolic blood pressure of $80 \mathrm{mmHg})$. The association was found to be statistically significant $(P<0.05)$. They also observed a significant difference in the frequencies of genotypes and alleles at the VDR locus. The FF, Ff, and ff genotypes exhibited frequencies of $53.6 \%, 35.7 \%$, and $10.7 \%$, respectively, in hypertensive individuals, and $34 \%, 51 \%$, and $15 \%$, respectively, in healthy normotensive subjects.

The risk for hypertension was calculated from the odds ratio (OR). The FF genotype showed a 2.25-fold and 2.20-fold higher risk for hypertension than the Ff and ff genotypes, respectively. Notably, the risk for hypertension was high in both men and women with the FF genotype (OR: 2.020 and 95\% Cl: $1.228-3.322$ in men, OR: 2.467 and $95 \% \mathrm{Cl}: 1.246-4.4881$ in women) and in individuals with a positive family history of hypertension (OR: 2.011 and 95\% Cl: 1.119-3.616), smoking (OR: 3.686 and 95\% Cl: 1.414-9.611), and alcohol consumption (OR: 2.239 and 95\% Cl: 0.983-5.096) [26].

In another study, Vaidya and coauthors [27] sought to understand the role of polymorphisms in plasma renin (RP) activity using the data of the subjects studied in the International Hypertensive Pathotype (HyperPATH) Consortium for investigating the pathophysiological and genotypic mechanisms involved in hypertension and cardiovascular diseases. In this study, 375 hypertensive (aged 40.1 to 56.5 years) and 146 normotensive (aged 29.0 to 50.8 years) Caucasian Americans of both sexes were investigated to determine whether the genetic variation of VDR was associated with RP activity and whether this interaction was independent of $25(\mathrm{OH}) \mathrm{D}$ levels. The study subjects received a high $(\geq 200 \mathrm{mmol} \mathrm{Na} / 24 \mathrm{~h})$ or low $(\leq 10 \mathrm{mmol}$ $\mathrm{Na} / 24 \mathrm{~h}$ ) Na dose for 5-7 days. At the end of the experiment, the F allele was associated with low RP activity in hypertensive patients $(\mathrm{P}<0.05)$. An association between Fok / polymorphism and $25(\mathrm{OH}) \mathrm{D}$ concentrations was not observed, suggesting that the frequency of the $F$ allele and high concentrations of $25(\mathrm{OH}) \mathrm{D}$ may have additive rather than mutual associations with respect to RP activity in hypertensive and normotensive individuals. These results indicate that the negative regulation of renin by $1,25(\mathrm{OH})_{2} \mathrm{D}_{3}$ is mediated in part by VDR.

Another study was conducted by Glocke and coauthors [28] to compare the prevalence of Fok I polymorphism in 101 elderly (> 90 years of age) and 208 young (<90 years old) subjects of both sexes (Caucasians of German descent). A negative effect of Fok I polymorphism on diastolic blood pressure was observed in the elderly group $(P<0.05)$, especially in those with the ff genotype because they had a lower mean blood pressure of $70.00 \pm 2.12 \mathrm{mmHg}$ than those with the FF genotype $(82.9 \pm 3.10 \mathrm{mmHg})$ and $\mathrm{Ff}$ genotype $(76.17 \pm 2.69 \mathrm{mmHg})$. The prevalence of hypertension was lower in subjects with $\mathrm{ff}$ and $\mathrm{Ff}$ genotypes than in those with FF genotype; however, the difference was not statistically significant. The lifespan of subjects can also be affected by this polymorphism.

Cottone and coauthors [29] conducted a study in 71 patients with essential hypertension and 72 control subjects, of both sexes, aged 18-75 years, in Italy. The frequencies of FF, Ff, and ff genotypes in hypertensive patients were $50.7 \%, 42.3 \%$, and $7.0 \%$, respectively, and in control subjects were $40.3 \%$, $50.0 \%$, and $9.7 \%$, respectively. The allelic frequencies of $\mathrm{F}$ and $\mathrm{f}$ were $71.8 \%$ and $28.2 \%$, respectively, in hypertensive patients, and $65.3 \%$ and $34.7 \%$, respectively in normotensive individuals. The diastolic blood pressure was different for all three genotypes of Fok / polymorphism $(P=0.018)$. Patients with the ff genotype had a higher diastolic blood pressure than those with the $\mathrm{Ff}$ genotype $(P=0.002)$. A negative correlation was observed between $25(\mathrm{OH}) \mathrm{D}$ levels and pulse blood pressure, and this correlation was statistically significant in patients with the $\mathrm{Ff}$ genotype $(r=-0.474, \mathrm{P}=0.035)$. There was no association between a specific genotype or allele and hypertension. An association between Fok I polymorphism and RP activity was also not observed.

Jia and coauthors [30] conducted a study in 2,409 hypertensive and 3,063 normotensive sexagenarian and septuagenarian Han Chinese subjects of both sexes. The correlation of Fok I polymorphism with decreased risk for hypertension after adjusting for confounding factors (sex, age, body mass index, total cholesterol, triglycerides, high-density lipoprotein and low-density lipoprotein cholesterol, and smoking) in men was significant. The OR and $95 \% \mathrm{Cl}$ for the additive, dominant, and recessive models were $0.828(0.74-$ $0.927 ; P=0.001), 0.75(0.631-0.89 ; P=0.001)$, and $0.816(0.67-0.995 ; P=0.044)$, respectively. Subjects with the $\mathrm{Ff} / \mathrm{ff}$ genotype had a lower blood pressure than those with the FF genotype $(p=0.002)$. The 
frequencies of $\mathrm{F}$ and $\mathrm{f}$ alleles were $55.9 \%$ and $44.1 \%$, respectively, in the hypertensive patients, and $54.3 \%$ and $44.7 \%$, respectively in control subjects.

In another study, Errouagui and coauthors [31] analyzed 177 hypertensive (aged 45.47 to 68.41 years) and 222 normotensive (aged 34.67 to 64.59) subjects of both sexes in Morocco, and found a strong association between Fok I polymorphism and $\mathrm{AH}$ in codominant, dominant, and recessive genetic models. The frequency of the $\mathrm{ff}$ genotype in hypertensive patients was significantly lower than that in the control subjects $(\mathrm{OR}=0.24,95 \% \mathrm{Cl}=0.10-0.58, \mathrm{P}=0.002)$. The mean concentrations of vitamin $\mathrm{D}$ in subjects with the FF, Ff, and ff genotypes were $28.06 \pm 10.57,29.04 \pm 11.97$, and $26.40 \pm 19.15 \mathrm{ng} / \mathrm{mL}$, respectively. However, the differences in the concentration of vitamin $D$ were not statistically significant between subjects with $\mathrm{FF}$ and $\mathrm{Ff}(\mathrm{P}=0.6463)$ and those with $\mathrm{FF}$ and $\mathrm{ff}(\mathrm{P}=0.0767)$ genotypes.

Gussago and coauthors [32] conducted a study in 70-year-old subjects and centenarians of both sexes in northern Italy. The frequencies of the FF, Ff, and ff genotypes in centenarians were $47.4 \%, 42.1 \%$, and $10.5 \%$, respectively, with $\mathrm{F}$ being the most frequent allele $(68.4 \%)$. In the control group comprising septuagenarians, the frequencies of the $\mathrm{FF}, \mathrm{Ff}$, and $\mathrm{ff}$ genotypes were $48.4 \%, 38.7 \%$, and $12.9 \%$, respectively, with $\mathrm{F}$ being the most frequent allele (67.8\%). Moreover, the prevalence of hypertension was higher in subjects with the FF genotype than in those with the $\mathrm{Ff}$ and ff genotypes $(P=0.015)$.

Ndiaye and coauthors [33] conducted a study in two phases. In the first phase, 1,912 French Caucasian adult subjects with a mean age of $51.13 \pm 10.02$ years were included; the subjects were predominantly women (51.3\%). Normotensive and hypertensive patients not on drug therapy were included in this group. In the second phase, 1,755 healthy Europeans from Greece, Ireland, and Portugal, with a mean age of $42.06 \pm$ 9.89 years were included; the subjects were predominantly men (67\%). The Fok l-f polymorphism of the VDR gene was significantly associated with diastolic $\left(P_{\text {adjusted }} \leq 4.93 \times 10^{-4}\right)$ and systolic $\left(P_{\text {adjusted }} \leq 9.48 \times 10^{-4}\right)$ blood pressure.

Two surveys were conducted during the Women's Genome Health Study (WGHS) to obtain blood pressure data and genotyping information for Fok ISNP in 23,294 women of European ancestry with a mean age of $54.7 \pm 7.1$ who participated in the International Consortium of Blood Pressure (ICBP). Wang and coauthors [34] did not find a correlation between Fok 1 -f polymorphism and hypertension, with beta $(\mathrm{SE})=$ $0.055 \pm 0.19$ and $P=0.77$ for systolic blood pressure, beta $(S E)=0.00096 \pm 0.13$ and $P=0.99$ for diastolic blood pressure, and beta $(\mathrm{SE})=0.054 \pm 0.11$ and $\mathrm{P}=0.63$ for pulse pressure.

Wang and coauthors [35] conducted a prospective study in 1,211 Caucasian American men with a minimum and maximum follow-up periods of 15.2 and 27.4 years, respectively. In this study, 695 subjects were diagnosed with hypertension. The prevalence of Fok I polymorphism was investigated in 885 subjects and the majority of hypertensive patients had a polymorphism of the VDR gene. The association of Fok I polymorphism with the risk for hypertension was found only in the recessive model. The ff genotype in model 2 had a multivariate hazard ratio (HR) of $1.32(95 \% \mathrm{Cl}: 1.03-1.70)$ for the incidence of hypertension. The correlation between $25(\mathrm{OH}) \mathrm{D}$ concentrations and the risk for hypertension was higher in subjects with the ff genotype than in those with the Ff and FF genotypes.

Fok I polymorphism affects the length and function of the VDR protein. The reduced activity of VDR is caused by the deficiency or excess of vitamin $D$ and inactivation of its biologically active form [28]. It is worth noting that the results of the studies by Swapna and coauthors [26], Glocke and coauthors [28], Jia and coauthors [30], Errouagui and coauthors [31], Gussago and coauthors [32], and Wang and coauthors [35] corroborate the hypothesis that Fok I polymorphism causes AH. Vaidya and coauthors [27] have shown that the regulation of RP activity is important to preventing $\mathrm{AH}$. In their study, they observed the effect of Fok I polymorphism on the regulation of RP activity. In order to understand this process, it is important to identify gene-gene or gene-environment interactions [34] as well as epistatic interactions that may be useful for the identification of undetected genetic markers by analyzing individual markers or assessing the combinatorial effect of the locus by other alternatives. The absence of comprehensive analysis may be the reason for the differences in the results of the cited studies [33].

It was noticed that the analyzed publications employed a variety of protocols and population groups, which can also cause differences in the results. Moreover, age and ethnicity of an individual are important factors for studying hypertension. The inhibition of renin activity and the subsequent increase in the levels of angiotensin II, a potent vasoconstrictor, can contribute to elevated blood pressure. Interestingly, the levels of $1,25(\mathrm{OH})_{2} \mathrm{D}_{3}$ affect renin expression. 1,25 $(\mathrm{OH})_{2} \mathrm{D}_{3}$ downregulates renin expression by suppressing, at least in part, CRE-mediated transcriptional activity that is activated by cAMP-PKA signaling and subsequent CREB phosphorylation. The recruitment of CBP / p300 to VDR blocks the binding of CREB to CRE, and inhibits transcription of the renin gene [36]. Figure 2. 


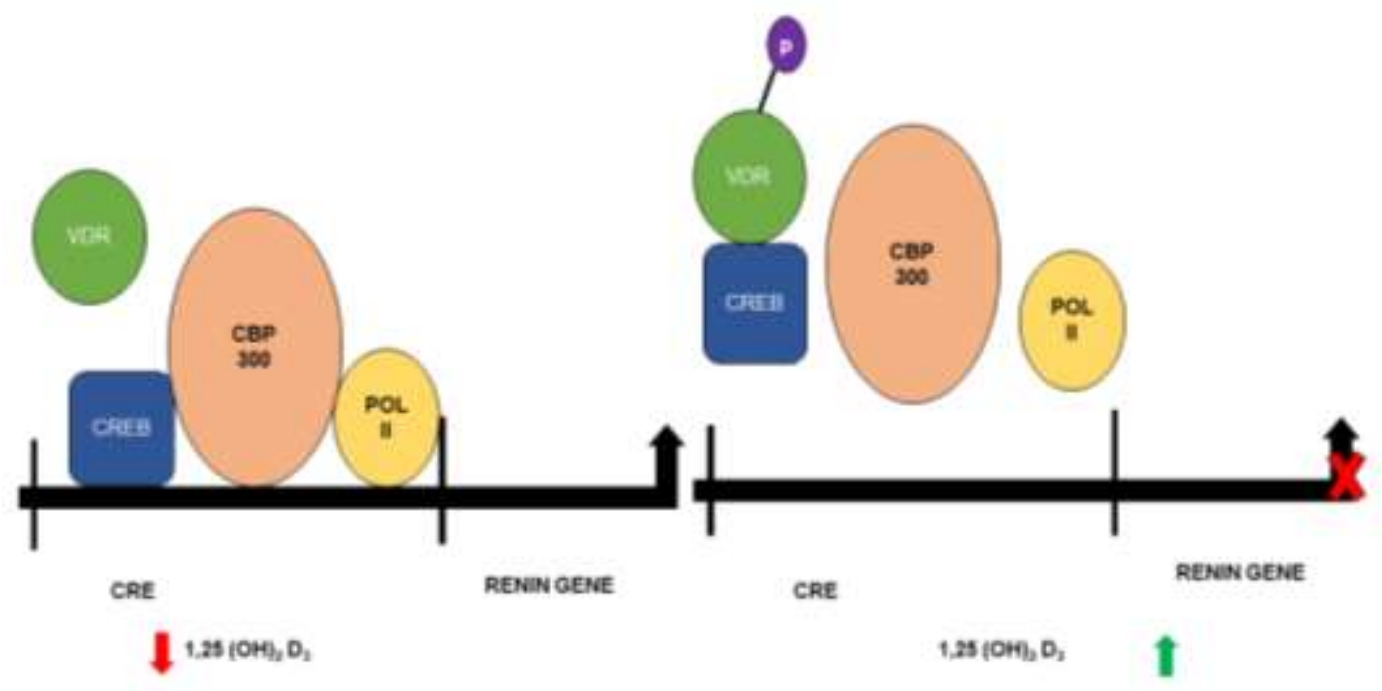

Figure 2. Mechanism proposed for action of vitamin D on the expression of renin. Adaptation [36].

The following points must be addressed in future studies:

- Determine the need for early blood pressure monitoring in individuals with Fok I polymorphism of the VDR gene to prevent the onset of $\mathrm{AH}$.

- Determine the efficacy of vitamin D supplementation to reduce the risk and delay the development of hypertension in individuals with Fok I polymorphism.

-Determine the optimal dose to achieve this effect.

\section{CONCLUSION}

Based on the data analysis of the selected studies, most of the publications showed an association between Fok / polymorphism and $\mathrm{AH}$. Although this result is promising, there are several limitations of these studies. The results of these studies cannot be expanded to other population groups because they did not consistently include representative samples with ethnic diversity. Additionally, all of the study participants were either adults or elderly, and one study was conducted on only one of the sexes.

These studies do not provide unanimous results regarding the risk for hypertension and its association with the frequency of Fok I genotypes. A correlation was found between AH and two different genotypes, ff and FF. It is unclear whether $25(\mathrm{OH}) \mathrm{D}$ levels are associated with Fok I polymorphism and hypertension because the results were inconclusive in a few studies investigating this association.

Funding: This research received no external funding.

Acknowledgments: We thank members of the Postgraduate Program in Food and Nutrition for administrative and technical support.

Conflicts of Interest: The authors declare no conflict of interest.

\section{REFERENCES}

1. Wu L, Sun D. Effects of calcium plus vitamin D supplementation on blood pressure: a systematic review and metaanalysis of randomized controlled trials. J Hum Hypertens. 2017 Sep;31(9):547-54.

2. Meehan M, Penckofer S. The Role of Vitamin D in the Aging Adult. J Aging Gerontol. 2014 Dec; 2(2):60-71.

3. Lategan $R$, Van den Berg VL, llich JZ, Walsh CM. Vitamin D status, hypertension and body mass index in an urban black community in Mangaung, South Africa. Afr J Prim Health Care Fam Med. 2016 Oct;8(1):e1-e5.

4. Forman JP, Giovannucci E, Holmes MD, Bischoff-Ferrari HA, Tworoger SS, Willett WC, et al. Plasma 25Hydroxyvitamin D Levels and Risk of Incident Hypertension. Hypertension [Internet]. 2007 May [cited 2019 Feb 6];49(5):1063-9. Available from:

https://www.ahajournals.org/doi/10.1161/HYPERTENSIONAHA.107.087288. 
5. Milovanovic M, Pesic G, Nikolic V, Jevtovic-Stoimenov T, Vasic K, Jovic Z, et al. Vitamin D deficiency is associated with increased IL-17 and Tnfa levels in patients with chronic heart failure. Arq Bras Cardiol. 2012 Mar;98(3):25965.

6. Scragg R, Sowers M, Bell C. Serum 25-hydroxyvitamin D, ethnicity, and blood pressure in the Third National Health and Nutrition Examination Survey. Am J Hypertens. 2007 Jul;20(7):713-9.

7. Dorjgochoo T, Ou Shu X, Xiang YB, Yang G, Cai Q, Li H, et al. Circulating 25-hydroxyvitamin D levels in relation to blood pressure parameters and hypertension in the Shanghai Women's and Men's Health Studies. Br J Nutr. 2012 Aug;108(3):449-58.

8. Torres YC, Pérez AF, Puerta RC, Valdez MV, Castillo IS. Vitamin D deficiency and hypertension. Supporting evidence. Rev Colomb Cardiol. 2016 Jan-Fev;23(1):42-8.

9. Li YC, Kong J, Wei M, Chen ZF, Liu SQ, Cao LP. 1,25-dihydroxyvitamin D(3) is a negative endocrine regulator of the rennin-angiotensin system. J Clin Invest. 2002 Jul;110(2):229-38.

10. Merke J, Milde P, Lewicka S, Hugel U, Klaus G, Mangelsdorf DJ, et al. Identification and Regulation of 1,25Dihydroxyvitamin D3 Receptor Activity and Biosynthesis of 1,25-Dihydroxyvitamin D3. Studies in Cultured Bovine Aortic Endothelial Cells and Human Dermal Capillaries. J Clin Invest [Internet]. 1989 Jun [cited 2019 Feb];83(6):1903-15. Available from: https://www.ncbi.nlm.nih.gov/pmc/articles/PMC303911/pdf/jcinvest000870127.pdf.

11. Merke J, Hofmann W, Goldschmidt D, Ritz E. Demonstration of 1,25(OH)2 vitamin D3 receptors and actions in vascular smooth muscle cells in vitro. Calcif Tissue Int. 1987 Aug;41(2):112-4.

12. Wang Y, Zhu J, DeLuca HF. Where is the vitamin D receptor? Arch. Biochem Biophys. 2012 Jul; 523(1)123-33.

13. Butler MG. Genetics of hypertension. Current status. J Med Liban. 2010 Jul-Sep;58(3):175-8.

14. Uitterlinden AG, Fang Y, van Meurs JBJ, Pols HAP, van Leeuwen JPTM. Genetics and biology of vitamin D receptor polymorphisms. Gene [Internet]. 2004 Sep [cited 2019 Feb 6];338(2):143-56. Available from: http://www.ncbi.nlm.nih.gov/pubmed/15315818.

15. Kulah E, Dursun A, Acikgoz S, Can M, Kargi S, Ilikhan S, et al. The relationship of target organ damage and 24hour ambulatory blood pressure monitoring with vitamin $D$ receptor gene Fokl polymorphism in essential hypertension. Kidney Blood Press Res. 2006 Nov;29(6):344-50.

16. Abd EGSS, Abdul SER, Metwali AA, Abd EGMS. Vitamin D receptor gene polymorphism and its association with 1,25-dihydroxyvitamin D3 in patients with Graves disease in an Egyptian population: a pilot study. Endocr Pract. 2012 Mar-Apr;18(2):132-9.

17. Arai $\mathrm{H}$, Miyamoto $\mathrm{K}$, Taketani $\mathrm{Y}$, Yamamoto $\mathrm{H}$, lemori $\mathrm{Y}$, Morita $\mathrm{K}$, et al. A vitamin $\mathrm{D}$ receptor gene polymorphism in the translation initiation codon: effect on protein activity and relation to bone mineral density in Japanese women. J Bone Miner Res. 1997 Jun;12(6):915-21.

18. Jurutka PW, Remus LS, Whitfield GK, Thompson PD, Hsieh JC, Zitzer H, et al. The polymorphic N terminus in human vitamin $D$ receptor isoforms influences transcriptional activity by modulating interaction with transcription factor IIB. Mol Endocrinol. 2000 Mar;14(3):401-20.

19. Whitfield GK, Remus LS, Jurutka PW, Zitzer H, Oza AK, Dang HT. Functionally relevant polymorphisms in the human nuclear vitamin D receptor gene. Mol Cell Endocrinol. 2001 May;177(1-2):145-59.

20. Legarth C, Grimm D, Wehland M, Bauer J, Krüger M. The impact of vitamin D in the treatment of essential hypertension. Int J Mol Sci. 2018 Feb; 19(2):455.

21. Wang L, Song Y, Manson JE, Pilz S, März W, Michaëlsson K, et al. Circulating 25-hydroxy-vitamin D and risk of cardiovascular disease: a meta-analysis of prospective studies. Circ Cardiovasc Qual Outcomes. 2012 Nov; 5(6):819-29.

22. Colin EM, Weel AE, Uitterlinden AG, Buurman CJ, Birkenhäger JC, Pols HA, et al. Consequences of vitamin D receptor gene polymorphisms for growth inhibition of cultured human peripheral blood mononuclear cells by 1,25 dihydroxyvitamin D3. Clin Endocrinol (Oxf). 2000 Feb;52(2):211-6.

23. Moher D, Liberati A, Tetzlaff J, Altman DC. Preferred reporting items for systematic review and meta-analyses: the PRISMA statement. Open Med. 2009 Jul;3:123-30.

24. Wells GA, Shea B, O'Connell D, Peterson J, Welch V, Losos M, et al. The Newcastle-Ottawa Scale (NOS) for assessing the quality of nonrandomised studies in meta-analyses. 2000. Available at: http://www.ohri.ca/programs/clinical_epidemiology/oxford.asp.

25. Loney PL, Chambers LW, Bennett KJ, Roberts JG, Stratford PW. Critical appraisal of the health research literature: prevalence or incidence of a health problem. Chronic Dis Can [Internet]. 1998 [cited 2019 Jul 4];19(4):170-6. Available from: https://www.ncbi.nlm.nih.gov/pubmed/10029513.

26. Swapna N, Vamsi UM, Usha G, Padma T. Risk conferred by Fokl polymorphism of vitamin D receptor (VDR) gene for essential hypertension. Indian J Hum Genet. 2011 Sep;17(3):201-6.

27. Vaidya A, Sun B, Forman JP, Hopkins PN, Brown NJ, Kolatkar NS, et al. The Fok1 vitamin D receptor gene 
polymorphism is associated with plasma renin activity in Caucasians. Clin Endocrinol (Oxf) [Internet]. 2011 Jun [cited 2019 May 11];74(6):783-90. Available from: https://www.ncbi.nlm.nih.gov/pmc/articles/PMC3089671/.

28. Glocke M, Lang F, Schaeffeler E, Lang T, Schwab M, Lang UE. Impact of vitamin D receptor VDR rs2228570 polymorphism in oldest old. Kidney Blood Press Res. 2013 Sep;37(4-5):311-22.

29. Cottone S, Guarino L, Arsena R, Scazzone C, Tornese F, Guarneri M, et al. Vitamin D receptor gene polymorphisms and plasma renin activity in essential hypertensive individuals. J Hum Hypertens. 2015 Aug;29(8):483-7.

30. Jia J, Shen C, Mao L, Yang K, Men C, Zhan Y. Vitamin D receptor genetic polymorphism is significantly associated with decreased risk of hypertension in a Chinese Han population. J Clin Hypertens (Greenwich). 2014 Sep;16(9):634-9.

31. Errouagui A, Charoute H, Ghalim N, Barakat A, Kandil M, Rouba H. Relationship with vitamin D receptor (RVD) gene and essential arterial hypertension in Moroccan population. Int J Innov Appl Stud [Internet]. 2014 [cited 2019 Mar];8(2):556-66. Available from: http://www.ijias.issr-journals.org/abstract.php?article=IJIAS-14-216-12.

32. Gussago C, Arosio B, Guerini FR, Ferri E, Costa AS, Casati M, et al. Impact of vitamin D receptor polymorphisms in centenarians. Endocrine. 2016 Aug;53(2):558-64.

33. Ndiaye NC, Said ES, Stathopoulou MG, Siest G, Tsai MY, Visvikis-Siest S. Epistatic study reveals two genetic interactions in blood pressure regulation. BMC Med Genet. 2013; 14(2):1-7.

34. Wang L, Chu A, Buring JE, Ridker PM, Chasman DI, Sesso HD. Common Genetic Variations in the Vitamin D Pathway in Relation to Blood Pressure. Am J Hypertens [Internet]. 2014 Nov [cited 2019 Feb 23];27(11):1387-95. Available from: http://www.ncbi.nlm.nih.gov/pubmed/24688000.

35. Wang L, Ma J, Manson JE, Buring JE, Gaziano JM, Sesso HD. A prospective study of plasma vitamin D metabolites, vitamin D receptor gene polymorphisms, and risk of hypertension in men. Eur J Nutr. 2013 Oct;52(7):1771-9.

36. Yuan W, Pan W, Kong J, Zheng W, Szeto FL, Wong KE, et al. 1,25-dihydroxyvitamin D3 suppresses renin gene transcription by blocking the activity of the cyclic AMP response element in the renin gene promoter. J Biol Chem [Internet]. 2007 Oct [cited 2019 Jul 4]; 282(41):29821-30. Available from: http://www.jbc.org/content/282/41/29821.long.

2020 by the authors. Submitted for possible open access publication under the terms and conditions of the Creative Commons Attribution (CC BY NC) license (https://creativecommons.org/licenses/by-nc/4.0/). 